

\section{Shirkah}

\section{Journal of Economics and Business \\ Vol. 1, No. 1, January-April 2016 \\ ISSN: 2503-4235 (p); 2503-4243 (e)}

\section{Editor in Chief}

Sri Walyoto

\section{Editorial Boards}

Ahmad Ihwan Setiawan, Faculty of Economics, Universitas Sebelas Maret

Dwi Condro Triono, Faculty of Islamic Economics and Business, IAIN

Surakarta

Fahmy Radhi, Faculty of Economics, Universitas Gadjah Mada

Jaka Sriyana, Faculty of Economics, Universitas Islam Indonesia

\section{Managing Editors}

M. Endy Saputro

M. Zainal Anwar

\section{Assistant to Editor}

Supriyanto

Shirkah Journal of Economics and Business is a peer-reviewed journal published three times a year (January-April, May-August and September-December) by Faculty of Islamic Economics and Business, Institut Agama Islam Negeri (IAIN/ State Institute for Islamic Studies) Surakarta Central Java, Indonesia. The main objective of Shirkah is to offer an academic space of exchange ideas and initiate the increase number of qualified article produced by postgraduate students, practitioners and academicians.

\section{Editorial Office}

Ruang Jurnal Shirkah

Lantai Dasar, Sayap Barat, Fakultas Ekonomi dan Bisnis Islam, IAIN Surakarta

Jln. Pandawa No. 1, Kartasura, Sukoharjo, Jawa Tengah Kode Pos. 57168

Phone (+62271) 781516 Fax: (+62271)782336

E-mail: shirkahiainsurakarta@gmail.com

Website: http://shirkah.or.id/ 


\section{Shirkah}

Journal of Economics and Business

Vol. 1, No. 1, January-April 2016

ISSN: 2503-4235 (p); 2503-4243 (e)

\section{Table of Contents}

\section{Articles}

Muthmainah

The Growth of Sharia Insurance in Indonesia 2015 - 2016

An Academic Forecast Analysis

Meilana Widyaningsih

$23-46$

The Effect of Material, Social and Activities Compensations

toward Work Performance Using Organizational Commitment

as The Mediator

Tri Wabyuni

$47-72$

The Influence of Technology Acceptance Model (TAM)

on The Users' Behavior of Sikesya Application in IAIN Surakarta

M. Nidaussalam

Mudaraba as a Model of Islamic Finance

Sri Maryati

$93-112$

Evaluating The Performance of Inventory Management

The Production Division of PT. Tiga Serangkai Surakarta

as a Case Study

Mardhiyaturrositaningsih

$113-126$

Sharia Banking's Profit Loss Finance in the Context of ASEAN Economic Community 


\title{
The Effect of Material, Social and Activities Compensations toward Work Performance Using Organizational Commitment as The Mediator
}

\author{
Meilana Widyaningsih \\ Finance and Sharia Banking, Graduate Program, \\ State Islamic University (UIN) Yogyakarta
}

\begin{abstract}
This study aims to determine the effect of material compensation, social compensation, and activities compensation on work performance through organizational commitment as the mediator. This study retrieved data through questionnaires (surveys). The population in this study were all employees of PT. Tiga Serangkai Pustaka Mandiri Surakarta, with taking 150 respondents for sampling purpose. Sampling technique in this study was a simple random sampling. The data were processed using Structural Equation Modeling (SEM) with the help of Analysis of Moment Structure (AMOS) version 20.0. The results of the data analysis found that 1) There is a significantly positive influence of social compensation variables on organizational commitment; 2) There is a positive significant effect of activity compensation on organizational commitment; 3) There is a significantly positive effect of activity compensation on job performance; 4) Organizational commitment does not mediate material compensation, social compensation, and activities compensation on job performance.
\end{abstract}

Keywords:

material compensation, social compensation, activities compensation, work performance, and organizational commitment, Tiga Serangkai Pustaka Mandiri

Human resources is one of organizational assets. Operationally, an organization needs to have strategies as a means to manage its human resources in order to obtain the organizational vision and mission. Human as the main actor of organizational aspects, determine the success of the 
organization as well as its sustainability.

Maximum and satisfy performance measurement can be seen from the achievement of its employee in performing their role within the organization. Achievement is not necessarily comes up as an appreciation from the employee to the organization where they are working. However, when it is not retained, employee achievement will soon vanished as the time goes by. Unmotivated employee in their organizations will contribute to the organizational setback and in turn their position would likely to be replaced by their competitors. The employee who are likely to achieve a good performance are those who have need to gain high performance and feel satisfy when they completed their job, and prefer the situations where there are moderate risks, where they could find and feel their contribution, those such employee are also love to obtain feedback about their performance (Dessler, 1984, p. 690).

Employee need to get constructive and instructive feedback as well as appreciation that would in turn change their knowledge into productivity that have been reconstructed and have best quality (Kreitner, 2003, p. 334). Hasibuan (2006, p. 117) stated that the compensation that an employee got from his work will be used to support his family life, as the consequence, every employee is hoping a compensation as approppriate as his performance. The higer the status of an employee in his organization, the higher the compensation he got and as the consequence would increase his work performance. This shows that the compensation plays an important role in work performance.

Compensation is a company technique to motivate and to pay an exchange to the employees' performance by an expectation; it would increase their work performance to gain the aim of the organization. Good work performance is assumed to foster the accomplishment of organization vision and mission and would increase organizations' 
competitiveness. Even though, in reality those ideas were not hundred percent true. Compensation in the form of facility and allowance was not always increase the contribution and commitment of the employee to have good achievement to support organizational vision and mission. For example, the absentism which is not appropriate with company's operating standard, raise a question does the compensation in the form of allowance given by the company with the goal to ease the employee's work has been used as its' goal? And whether the responsibility in accordance with all ease of work provided by the company have contribute to the development of organizational commitment?

Compensation in the form of authority, delegation, and power, in reality are susceptible to be misused. It is very often that people in the managerial level were less attentive to their subordinate even though they have more authority. On the other hand, in determining compensation policy, a company should pay attention to many factors. Bangun (2012, p. 254) explained that mistakes in establishing compensation could impacted in company's loss. This is because cost for human resource in a company remains high, reach $75 \%$ of the total production cost and sale. On the other hand, if the conpensation paid is too low and not suitable with employees' hope it would cause big turnover and resulted in high labor turnover (Bangun, 2012, p. 254).

Michael and Harold (1993, p. 443) divide compensation into three forms, they are material, social and activity compensation. Material compensation is not only given in the form of material such as bonus, and comission, but it also comprises of any kind of physical reinforcer such as parking facility, telephone and comfortable office, as well as many other kinds of subsidies like pension allowance and health insurance. Compensation has close relationship with organizational commitment. Employee who feel satisfies with the compensation they got would likely 
to influence their commitment toward their organization. Meyer et. al (2002) explained three dimensions of commitment, they are commitment as an affective attachment to the organization, commitment seen as a cost needed if one leave the organization and commitment as responsibility of an employee to stay in an organization. It can be concluded that commitment involves element of will, need, and responsibility.

\section{Three Principal Performances}

According to Ruyatnasih et. al. (2011), work performance is qualitative and quantitative work result achieved by an employee in conducting their job based on responsibility that is given to them. Work performance is a compound of three important factors, such as ability and interest of an employee, ability and acceptance of a work delegated to an employee, and the last role and motivation level of the employee. In its application, the higher those three factors, the higher employees' work performance (Hasibuan, 2006, p. 94).

Dessler (1984, p. 513) states that work performance assessment or performance appraisal is an effort to compare actual employee performance with the work performance expected from the employee. Hasibuan, (2006, p. 87) explained that existence of performance appraisal shows manager attention as a result it would encourage the employee to have spirit to work. But the appraisal should be followed by objective and honest assestment as well as its follow up such as promotion, demosion, development, and other kind of remuneration.

Further, Hasibuan (2006, p. 90) stated that for employee, performance appraisal would made them satisfy with themselves, and feel that the system asses their performance fairly and will accept the feedback consciously so that they can accept that as a fact and will encourage the employee to have better work performance. For the scompany, performance 
appraisal could implement the priciple of the right man in the right place.

In terms of appraising the performance, Sanusi (2012, p. 73) states that the influential dimensions toward employee performance consist of six components of works. The quality of work; the quality of work are assesed from work are the neatness, accuracy and completeness of work. The volume of work; the indicators for volume of work are rapidity in work completion as well as work consistency. Initiative; initiative is ability to think originally and based on own initiation to analyse, asses, create, reasoning, concluding, as well as making decision to solve the problem they face (Hasibuan, 2006). Task mastery; task mastery is ability to understand the task, skills, technique implementation, and ability to use the available devices (Sanusi, 2012, p. 73). Reliability; reliability is the autonomy in completing the task on time with minium supervision (Sanusi, 2012, p. 73). Presence; presence level depict the working discipline, which show employee responsibility in completing work standard or working days established by the company (Supiatni, 2011).

\section{Organizational Commitment}

Sutrisno (2010, p. 296) defines organizational commitment as the employee loyalty toward their companies, and it is also a process to express their attention and participation to their organization. Organizational commitment is a psychological condition that depict the relation between the employee and the organization (Suprana dan Ratnawati, 2012). Meyer et. al. (2002) define three components of organizational commitment, they are: afective commmitment, continuance commitment, and normative commitment. Meyer et. al. (2002) also explained that affective commitment lies emotional bound among the employees to their organization in the form of identification and involvement in organizational activities. Employee who showed efective and tight commitment will continue 
their membership in the organization because they are willing to do it. In addition, Meyer et. al (2002) mentioned that continuance commitment tend to the awareness of the loss that might be faced if the employee leave their organization. Those who have high continuance commitment are those who are in need of their job.

For the normative commitment, Meyer et. al (2002) defined it as an individual who feel that she has responsibility to continue their membership in an organization. The employee who have high normative commitment would feel that they should stay in the organization. On the other hand, Hasan (2012) explained that Islam view profession as a maximum commitment and seriousness in doing the task. This profesional character has been conceived in the Qur'an Shura al Isra article 84, "Say: Each one doth according to his rule of conduct, and thy Lord is Best Aware of him whose way is right."

\section{Compensation and Its Contents}

Compensation is everything received by employee as the remuneration for their work (Al Afghoni and Wahyudi, 2011). In turn, Hasibuan (2006, p. 118) explained that compensation is income in the form of money, or direct or indirect materials which is received by the employee as remuneration given by the organization in return of their job. Other definition of compensation is any kind of payment or return which is paid by the organization to the employee as the remuneration of their contribution to support the organization obtaining its goals (Supiatni, 2011).

According to Sumarni and Soeprihanto (2000: 27) the types of compensation according to national wage research council are:

1). Financial compensation comprises of:

a). Direct (wage, salary, commision, bonus, etc.) 
b). Indirect (any kinds of insurance, social security, etc.)

2). Non financial involves:

a). The Job (opportunities, attractiveness and responsibility that lies in a certain job)

b). Job environment (any kinds of job environment that encourage and build good and healthy job environment)

Michael and Harold (1993, p. 443) divide compensation into three, they are:

1). Material compensation

Material compensation covers not only material things like salary, bonus and commission, but also any kinds of physical reinforcer such as parking facilities, telephone, comfortable office, and any kinds of allowance such as pension subsidy, and health insurance. Those material compensation comprises of:

a) Salary

Basic salary is a basic compensation received by employee usually in the form of wage or salary, while salary itself is a constant remuneration for each period without considering the number of hours worked, while wage is a return of work which is counted directly from the number of worked hours (Mathis dan Jackson, 2006, p. 420).

b) Incentive

It is involved the non-fixed income, defined with as compensation relate to team, individual, and organizational work. It is also plan's efforts to provide employer with real award for above average achievemnt (Mathis and Jackson, 2006, p. 455).

c) Allowance

Allowance is an indirect appreciation from the company granted to the employee or a group of employee as an additional compensation 
for the employee because of organizational membership (Mathis dan Jackson, 2006, p. 481). Allowance which is given by the company was commonly took the form of health insurance, pension allowance, holidays allowance which is paid in the form of salary even though the employee was not working during holidays, leave, or feast.

d) Facility

Kamus Besar Bahasa Indonesia (KBBI) defines facility as a means to smooth functions implementation. In the work place facility could be defined as anything that enforce better performance because the employee feel easy and comfortable in performing his/her responsibility in the organization. Those facilities involve office, telephone, AC, parking area, and the like which support and ease the employee in their work.

e) Commision

Commision is compensation which is counted as percentage of selling in a unit or currency unit, which is used largely in selling activities (Mathis dan Jackson, 2006, p. 465).

f) Bonus

Bonus is one salary which is not part of employees' basic salary (Mathis and Jackson, 2006, p. 462).

g) Comfortable working place

Provision of comfortable working place which is suitable with employees' tasks would encourage at home feeling for employees in completing their task. Room comfortable could be conducted by designing the room layout based on employees tasks.

2). Social compensation

This form of compensation is closely related to the need to interract with others. This compensation took forms such as status, recognition as 
expert in employees field, appreciation on the achievement, promotion, certainty of tenure, recreation, formation of decision maker groups, and ad hoc group to solve company's problems. Social compensation dimensions are:

a) Status

Status is a condition or position (man, body, etc) in its relation with community surround them $(K B B I)$. Status owned by employees as part of the organization would become self image of the employees in their community so that they feel of having role and taking part in the organization.

b) Recognition

Recognition from the company that an employee is an expert in his/her field. That recognition can be implemented by placing her in the right position based on her skills, experties and ability.

c) Appreciation

According to Kamus Besar Bahasa Indonesia, apppreciation is an action of respect or reverence of a thing. Appreciation which is given to the employees based on achievements. Employees acievement should be appreciated through giving reward to motivate the employee so that they work better.

d) Certainty of tenure

Kamus Besar Bahasa Indonesia defines certainty as a certain and permanent condition. Certainty of tenure make the employee work without worrying of retirement or demotion.

e) Recreation

Recreation is every activities to refresh the employees' physical and thinking. Recreation is designed to develop employees happiness as well as spirit of team work (Mathis and Jackson, 2006, p. 480). Recreation could take forms of activities such as outbond, increase 
natural familiarity, as well as visit to other companies.

f) Ad hoc group formation for decision making

Kamus Besar Bahasa Indonesia defines group as a group which has organizational structure and strict rules and created by intention by its members to organize the relationship among its members. Whereas, decision is any kind of decision set (after being considered, thoughts, etc). Consequently, those meant by group of decision making is an intended group created to solve certain problem which need special treatment so that it could be solved as soon as possible regarding time limit and fairly. The ad hoc group created to make decision is performed to give space for employees to interact freely with each other.

3). Activities compensation

Activities compensation is a compensation that able to compensate the employees who do not like to do specific job by givng them opportunity to conduct specific activities they like. The form of activities compensations are like giving "power" to an employee to undertake different activities of his/her routine job to avoid work bored, responsibility and authority delegation, participation in decision making, and training to develop personality. The following are the dimensions of activities compensation :

a) Power

Power is an ability of a person or group to control other people or group using their charisma, authority, or physical power $(K B B I)$. Power which is given to the employee as a compensation from the company, give them power to work beyond their tasks. It could minimize wearyness of the employees in their work.

b) Delegation

If authority is a tool to act and decide, authority delegation is a the key for organizatioan dynamic when a delegator, although has 
delegated part of her authority, yet in the same time the delegator is still holding her authority (Hasibuan, 2006, p. 74).

c) Authority

Authority is a basis for action, conducting one's work, and performing tasks in an organization (Hasibuan, 2006, p. 66). Hasibuan, has also mentioned kinds of authority, they are:

(1) Line authority

(2) Staff authority

(3) Functional authority

(4) Personality authority

d) Responsibility

Responsibility is the compulsory to conduct all the responsibility as well as task that is imposed to one as a consequence of authority to her subordinate so that the authority should be accountable (Hasibuan, 2006, p. 70).

e) Training and development

Mangkunegara Sikula (2001, p. 44) explained that training and development is a process of short education using sistematic and organized procedure where non managerial employees to learn technical skills and knowledge in a limited purpose.

Compensation in shariah perspective, like wage is called ujrah in Islam. Wage is a form of compensation given in response to the service performed by the labor. To understand the definition of wage in islam more comprehensively, bellow is the translation of Shura At-Taubah article 105:

"And say (unto them): Act! Allah will behold your actions, and (so will) His messenger and the believers, and ye will be brought back to the Knower of the Invisible and the Visible, and He will tell you what ye used to do." 
Which was then explained in the shura An-Nahl article 977 as follow: "Whosoever doeth right, whether male or female, and is a believer, him verily we shall quicken with good life, and We shall pay them a recompense in proportion to the best of what they used to do."

The Prophet Muhammad Shallallahu 'alaihi wa sallam emphasized the important of decent wages in a hadits:

"they (your maids and slaves) are your brother, Allah placed them under your care, so whoever owned brothers under his care he should give them meals the same as what he eats and give them clothes like what he wears, and not burden them with a very hard job, and if you imposed them with such tasks, you should help them (doing it)." (H.R.Muslim)

\section{Framework, Hypothesis dan Method}

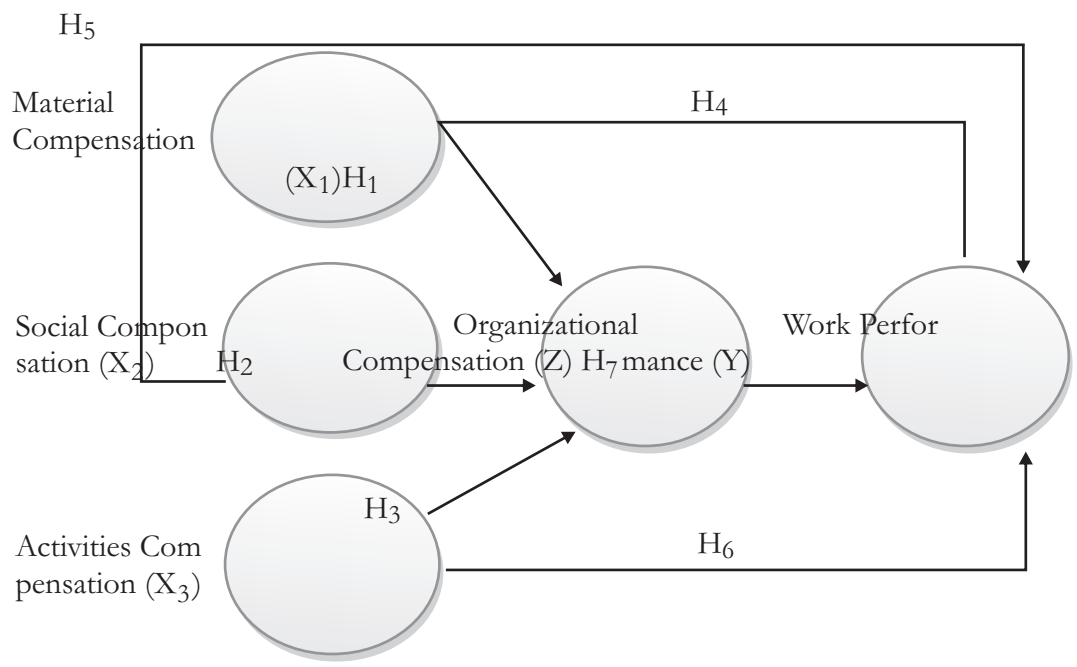

Source: Jurnal Penelitian Djati (2003) has been modified

1. $\mathrm{H}_{1}=$ the higher material compensation the more increasing employees commitment to the organization.

2. $\mathrm{H}_{2}=$ the higher social compensation the more increasing employees 
organizational commitment.

3. $\mathrm{H}_{3}=$ the higher activities compensation the more increasing employees organizational commitment.

4. $\mathrm{H}_{4}=$ the higher activities compensation the more increasing eployees work performance.

5. $\mathrm{H}_{5}=$ the higher social compensation the more increasing employees work performance.

6. $\mathrm{H}_{6}=$ the higher material compensation the more insreasing employees work performance.

7. $\mathrm{H}_{7}=$ the higher organizational commitment the more increasing employees work performance.

The population of this research is all PT. Tiga Serangkai Pustaka Mandiri employees. The sampel which is used in the research is the employees PT. Tiga Serangkai Pustaka Mandiri Wilayah Surakarta using simple random sampling technique, without considering the stratum in the population (Sugiyono, 2012, p. 118). The number of sample used are 150 respondent. The questioners are distributed to all the sample of this research using likert scale.

Dependent variable $(\mathrm{Y})$ used is work performance. Intervening variable $(Z)$ used is organizational commitment, while as the independent variable are material compensation, social compensation, and activities compensation. Analytical tools which used in this research is structural equational modelling (SEM). 


\section{Model Compatibility Test}

Test result of goodness-of-fit model can be seen from:

The result of Goodness-of-Fit model test

\begin{tabular}{|c|c|c|c|c|}
\hline No & Index & Critical Value & Result & Information \\
\hline 1 & Chi-Square $(\chi 2)$ & $\begin{array}{c}\text { Expected to be } \\
\text { small }\end{array}$ & 532,465 & Good \\
\hline 2 & Probability level & $\geq 0,05$ & 0,310 & Good \\
\hline 3 & $C M I N / D F$ & $\leq 2,00$ & 1,030 & Good \\
\hline 4 & $C F I$ & $\geq 0,95$ & 0,993 & Good \\
\hline 5 & RMSEA & $\leq 0,08$ & 0,014 & Good \\
\hline 6 & $T L I$ & $\geq 0,95$ & 0,992 & Good \\
\hline 7 & $G F I$ & $\geq 0,90$ & 0,834 & Marginal \\
\hline 8 & $A G F I$ & $\geq 0,90$ & 0,809 & Marginal \\
\hline
\end{tabular}

Source: primary data processed, 2014

Based on measurement result of each criteria goodness of fit model on the above table, it is known that the value of chi-square as much as 532,465 with the level of probability $0,310 \geq 0,05$, this proved that measurement model used in this research has good result or acceptable. The value of CMIN/DF in this model is 1,030 with the requirement of result test $\mathrm{CMIN} / \mathrm{DF} \leq 2,0$, indicate that measurement model which is used has good result or acceptable.

By considering recommended value of $\geq 0,95$, the value of CFI is 0,993 shows that the applied model has good result and acceptable. The RMSEA value is 0,014 shows that the model has good result and applicable. The recommended value of $\geq 0,95$, can be concluded that this model indicate suitability level that acceptable with the TLI value of 0,992 . The acceptability level that is recommended by GFI $\geq 0,90$, the model has GFI value of 0,834 that could be stated that the suitability level of the model that is used has marginal value. 
Adjusted goodness of fit index (AGFI) as an index development of GFI, is the index which has been adjusted to the ratio of degree of freedom model and has been proposed using degree of freedom from null model. With the acceptance value recommended by AGFI $\geq 0,90$, the model resulted the value of AGFI as much as 0,809 that could be said to have good suitability level or marginal.

\section{Full Structural Model}

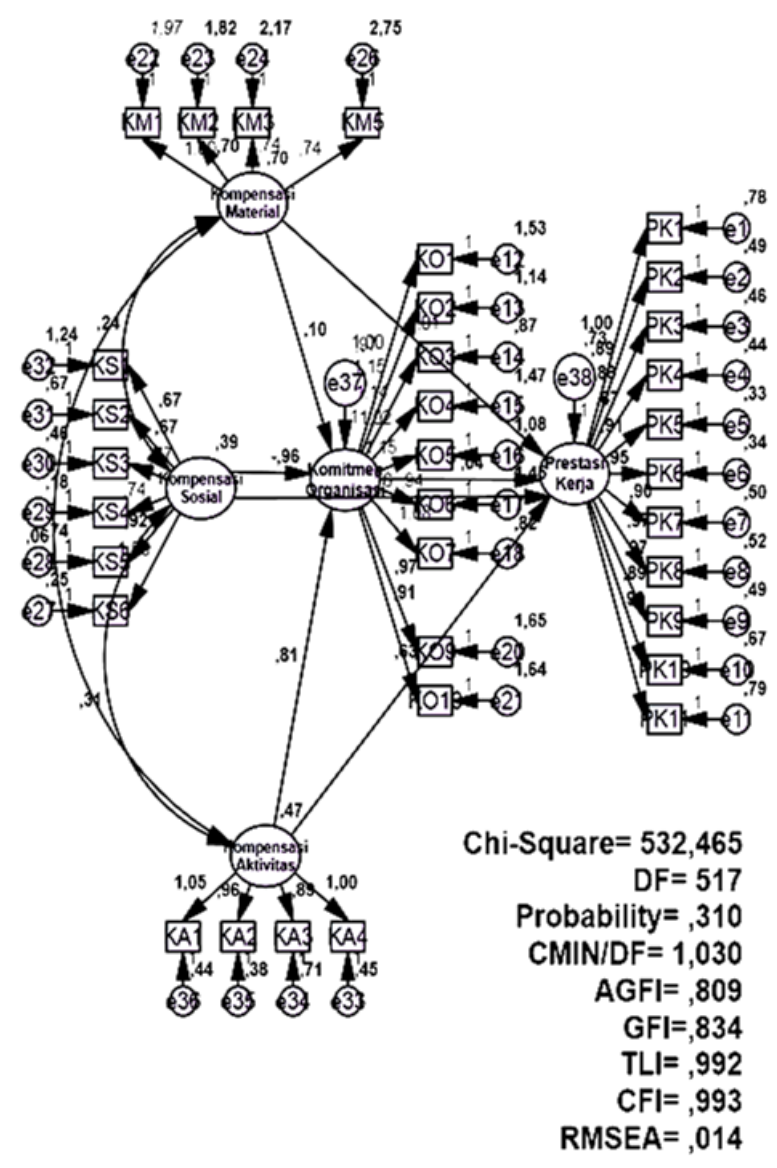

Vol. 1 No. 1, January - April 2016 


\section{Causality Test (Regression Weight)}

Causality test (Regression Weight) is used to identify the influence between variables used in the research and to explain whether the hypothesis could be accepted or not by examining C, R, and its probability. Bellow is the result of regression weight of this research:

Regression Weights: (Group number 1 - Default model)

\begin{tabular}{|l|l|l|r|r|r|r|r|}
\hline & & & $\begin{array}{r}\text { Esti } \\
\text { Mate }\end{array}$ & S.E. & C.R. & P & Label \\
\hline $\begin{array}{l}\text { Organizational } \\
\text { Commitment }\end{array}$ & $<---$ & $\begin{array}{l}\text { Material } \\
\text { Compensation }\end{array}$ &, 101 &, 236 &, 426 &, 670 & par_30 \\
\hline $\begin{array}{l}\text { Organizational } \\
\text { Commitment }\end{array}$ & $<--$ & $\begin{array}{l}\text { Activities } \\
\text { compensation }\end{array}$ &, 805 &, 351 & 2,296 &, 022 & par_32 \\
\hline $\begin{array}{l}\text { Organizational } \\
\text { commitment }\end{array}$ & $<--$ & $\begin{array}{l}\text { Social } \\
\text { compensation }\end{array}$ &,- 958 &, 454 & $-2,112$ &, 035 & par_39 \\
\hline $\begin{array}{l}\text { Work } \\
\text { Performance }\end{array}$ & $<--$ & $\begin{array}{l}\text { Material } \\
\text { compensation }\end{array}$ &, 014 &, 190 &, 075 &, 940 & par_31 \\
\hline $\begin{array}{l}\text { Work } \\
\text { Performance }\end{array}$ & $<--$ & $\begin{array}{l}\text { Activities } \\
\text { compensation }\end{array}$ &, 633 &, 301 & 2,105 &, 035 & par_33 \\
\hline $\begin{array}{l}\text { Work } \\
\text { Performance }\end{array}$ & $<---$ & $\begin{array}{l}\text { Social } \\
\text { compensation }\end{array}$ &, 160 &, 377 &, 425 &, 671 & par_37 \\
\hline $\begin{array}{l}\text { Work } \\
\text { Performance }\end{array}$ & $<---$ & $\begin{array}{l}\text { Organizational } \\
\text { commitment }\end{array}$ &, 041 &, 088 &, 471 &, 638 & par_38 \\
\hline
\end{tabular}

Source: primary data processed, 2014

\section{1) Hipotesis 1}

Estimated parameter to examine the influence of organizational commitment $\leftarrow$ material compensation showed the value C.R as much as 0,426 with the value of probability 0,670 . The value of C.R 0,426 which is less from 1,96 (the value in tabel $\mathrm{z}$ at $\alpha=5 \%$ ) and the probability which is higher from 0,05 showed that $\mathrm{Ha}$ is rejected, it means that material compensation was not significantly influenced the organizational commitment of employees to PT. Tiga Serangkai 
Pustaka Mandiri.

2) Hypothesis 3

Estimation parameter to test organization commitment effect $\leftarrow$ activities compensation shows C.R. value of 2.296 with probability of 0.022 . C.R value of 2.296 bigger than 1.96 ( $\mathrm{z}$ table value in $\alpha=5 \%$ ) and probability smaller than 0.05 shows $\mathrm{Ha}$ is accepted. It means activities compensation has significant effect on organization commitment at PT. Tiga Serangkai Pustaka Mandiri.

3) Hypothesis 4

Estimation parameter to test work achievement effect $\longleftarrow$ material compensation shows C.R. value of 0.075 with probability of 0.940. C.R value of 0.075 smaller than 1.96 ( $\mathrm{z}$ table value in $\alpha=5 \%$ ) and probability smaller than 0.05 shows $\mathrm{Ha}$ is rejected. It means material compensation does not have significant effect on work achievement at PT. Tiga Serangkai Pustaka Mandiri.

4) Hypothesis 5

Estimation parameter to test work achievement effect $\leftarrow$ social compensation shows C.R. value of 0.425 with probability of 0.671 . C.R value of 0.425 smaller than 1.96 ( $\mathrm{z}$ table value in $\alpha=5 \%$ ) and probability bigger than 0.05 shows $\mathrm{Ha}$ is rejected. It means material compensation does not have significant effect on work achievement at PT. Tiga Serangkai Pustaka Mandiri.

5) Hypothesis 6

Estimation parameter to test work achievement effect $\leftarrow$ activities compensation shows C.R. value of 2.105 with probability of 0.035 . C.R value of 2.105 bigger than 1.96 ( $\mathrm{z}$ table value in $\alpha=5 \%$ ) and probability smaller than 0.05 shows $\mathrm{Ha}$ is accepted. It means activities compensation has significant effect on work achievement at PT. Tiga Serangkai Pustaka Mandiri. 
6) Hypothesis 7

Estimation parameter to test work achievement effect $\leftarrow$ organization commitment shows C.R. value of 0.471 with probability of 0.638 . C.R value of 0.471 smaller than 1.96 ( $\mathrm{z}$ table value in $\alpha=5 \%$ ) and probability bigger than 0.05 shows $\mathrm{Ha}$ is rejected. It means organization commitment does not have significant effect on work achievement at PT. Tiga Serangkai Pustaka Mandiri.

Direct Effect, Indirect Effect, and Total Effect Analysis

\begin{tabular}{lrrrrr}
\hline & $\begin{array}{r}\text { Activities } \\
\text { Compensation }\end{array}$ & $\begin{array}{r}\text { Social } \\
\text { Compensation }\end{array}$ & $\begin{array}{r}\text { Material } \\
\text { Compensation }\end{array}$ & $\begin{array}{r}\text { Organization } \\
\text { Commitment }\end{array}$ & $\begin{array}{r}\text { Working } \\
\text { Acievement }\end{array}$ \\
\hline $\begin{array}{l}\text { Organization } \\
\text { Commitment }\end{array}$ & 0,521 & $-0,565$ & 0,080 & 0,000 & 0,000 \\
\hline $\begin{array}{l}\text { Working } \\
\text { Achievemnt }\end{array}$ & 0,435 & 0,100 & 0,012 & 0,044 & 0,000 \\
\hline
\end{tabular}

Standardized Direct Effects (Group number 1 - Default model)

Source: Processed Primary Data, 2014

The table shows direct effect of activities compensation on organization commitment is 0.521 ; social compensation on organization commitment is -0.565 , material compensation on organization commitment is 0.080 . The direct effect of activities compensation on work achievement is 0.435 , social compensation on work achievement is 0.100 , material compensation on work achievement is 0.012 , and organization commitment on work achievement is 0.044 


\begin{tabular}{lrrrrr}
\hline & $\begin{array}{r}\text { Activities } \\
\text { Compensation }\end{array}$ & $\begin{array}{r}\text { Social } \\
\text { Compensation }\end{array}$ & $\begin{array}{r}\text { Material } \\
\text { Compensation }\end{array}$ & $\begin{array}{r}\text { Organization } \\
\text { Commitment }\end{array}$ & $\begin{array}{r}\text { Working } \\
\text { Acievement }\end{array}$ \\
\hline $\begin{array}{l}\text { Organization } \\
\text { Commitment }\end{array}$ &, 000 &, 000 &, 000 &, 000 &, 000 \\
\hline $\begin{array}{l}\text { Working } \\
\text { Achievemnt }\end{array}$ &, 023 &,- 025 &, 003 &, 000 &, 000 \\
\hline
\end{tabular}

Standardized Indirect Effects (Group number 1 - Default model)

Source: Processed Primary Data, 2014

The table above shows indirect effect of each construction to certain construction. Activities compensation indirect effect on work achievement with organization commitment is 0.023 . Social compensation on work achievement with organization commitment is -0.025 . Material compensation on work achievement with organization commitment is 0.003 .

\begin{tabular}{lrrrrr}
\hline & $\begin{array}{r}\text { Activities } \\
\text { Compensation }\end{array}$ & $\begin{array}{r}\text { Social } \\
\text { Compensa-tion }\end{array}$ & $\begin{array}{r}\text { Material } \\
\text { Compensation }\end{array}$ & $\begin{array}{r}\text { Organization } \\
\text { Commitment }\end{array}$ & $\begin{array}{r}\text { Working } \\
\text { Acievement }\end{array}$ \\
\hline $\begin{array}{l}\text { Organization } \\
\text { Commitment }\end{array}$ &, 521 &,- 565 &, 080 &, 000 &, 000 \\
\hline $\begin{array}{l}\text { Working } \\
\text { Achievemnt }\end{array}$ &, 458 &, 075 &, 015 &, 044 &, 000 \\
& & & & &
\end{tabular}

\section{Standardized Total Effects (Group number 1 - Default model)}

Source: Processed Primary Data, 2014

The table above shows total effect of each construction of another construction. Activities compensation total effect on organization commitment is 0.521 ; social compensation on organization commitment is -0.565 ; and material compensation on organization commitment is 0.080. Those three total effects have the same amount with the direct effect, due to no other relation able to affect organization commitment power. Activities compensation total effect on work achievement with organization commitment is 0.458 ; social compensation on work achievement with 
organization commitment is 0.075 ; material compensation on work achievement with organization commitment is 0.015 ; and organization commitment on work achievement is 0.044

Base on the hypothetical test of empirical data gained in this research shows organization commitment does not mediate material, social and activities compensation on work achievement. It is shown on:

\section{Regression Weights: (Group number 1 - Default model)} Mediator Variable

\begin{tabular}{llll}
\hline & & & C.R \\
\hline $\mathrm{KO}$ & $<---$ & KM & 0,670 \\
\hline $\mathrm{KO}$ & $<---$ & KA & 0,022 \\
\hline $\mathrm{KO}$ & $<---$ & KS & 0,035 \\
\hline PK & $<---$ & KO & 0,638 \\
\hline
\end{tabular}

Source: Processed Primary Data, 2014

It due to organization commitment is only affected by activities compensation and social compensation. Material compensation does not have effect organization commitment and organization commitment does not have effect on work achievement. It concludes organization commitment could not mediate material, social, and activities compensation on work achievement.

This research result is different of Suprana and Ratnawari research (2012) which concludes satisfaction compensation has significant effect of employer's organization commitment. It also has different result of research by Djati (2003) stated organization commitment could mediate material, social and activities compensation on work achievement. 


\section{Conclusion}

Material compensation does not have significant effect on organization commitment. Social and material compensation have significant effect on organization commitment. Work achievement dependence variable is only significantly affected by activities compensation. Material and social compensation do not have significant effect on work achievement.

Company compensation in goods format does not create a significant commitment for the employers. The employers prefer social and activities compensation to establish and enhance work loyalty on organization. PT Tiga Serangkai Pustaka Mandiri employer's work achievement is more affected by activities compensation. Activities leniency in work finishing stimulate employer to gain high achievement.

Organization commitment doest not have significant effect on work achievement, and organization commitment does not mediate material, social, and activities compensation effect on work achievement. Employers' commitment on PT Tiga Serangkai Pustaka Mandiri does not stimulate high achievement of their work, and commitment does not indirectly affect on every kind of compensations accepted due to their work achievement. 


\section{References}

Al Afghoni, Muhammad Nur Jamaluddin dan Wahyudi, Amin. (2011). Pengaruh Kompensasi Dan Kepuasan kerja Terhadap Kinerja Guru Dengan komitmen Organisasi Sebagai Variabel Intervening. Jurnal Manajemen Sumberdaya Manusia. 5 (1). 42-53.

Bangun, Wilson. (2012). Manajemen Sumber Daya Manusia. Jakarta: Erlangga

Dessler, Gary. (1984). Manajemen Personalia Teknik Dan Konsep. Jakarta: Erlangga

Hasibuan, Malayu S.P. (2006). Manajemen Dasar, Pengertian, Dan Masalah. Jakarta: Bumi Aksara

Kreitner, Robert (Bob). (2003). Perilaku Organisasi. Jakarta: Salemba Empat

Mathis, Robert L dan Jackson, John H. (2006). Manajemen Sumber Daya Manusia. Jakarta: Salemba Empat (Terjemahan)

Meyer et. al. (2002). Affective, Continuance, and Normative Commitment to the Organization :A Meta-analisys of Antecedent, Correlates, and Consequences. Journal of Vocational Behaviour 61, 20-62.

Michael, Leibunon dan Weintein, Harold P. (1993). Money Is Everything. Annual Report HR

Ruyatnasih, dkk. (2013). Pengaruh Kompensasi Terhadap Prestasi Kerja Karyawan pada Divisi Engineering PT. Bridgestone Karawang. Jurnal Manajemen vol. 10 No. 3.

Sanusi, Anwar. (2012). Metodologi Penelitian Bisnis. Jakarta: Salemba Empat

Sumarni, Murti dan Soeprihanto, John. (2007). Pengantar Bisnis: DasarDasar Ekonomi Perusahaan. Yogyakarta: Liberty

Supiatni, Ni Nyoman. (2011). "Pengaruh Kompensasi, Diklat, Dan Disiplin Kerja Terhadap Prestasi Kerja Karyawan Di Hotel Mercure Sanur". Jurrnal Bisnis dan Kewirausahaan 7 (2). 
Suprana, Riski dan Ratnawati, Intan. (2012). “Analisis Pengaruh Kepuasan Kompensasi Dan Komitmen Organisasional Terhadap Kinerja Karyawan”. Diponegoro Journal of Management 1 (1), 439-445.

Sutrisno, Edy. (2010). Budaya Organisasi. Jakarta: Kencana

\section{Online}

Putra Hasan, Fikri. "Konsep Budaya Organisasi Secara Islami”, retrieved form http://fikriputrahasan.wordpress.com/2012/12/11/konsepbudaya-organisasi-secara-islami/ 26 Desember 2013)

Vol. 1 No. 1, January - April 2016 
Vol. 1 No. 1, January - April 2016 